\title{
LEGIONELLA SPP. IN SELECTED PUBLIC UTILITY BUILDINGS IN POLAND IN 2009-2013
}

\section{WYSTEPOWANIE BAKTERII LEGIONELLA SP. W WYBRANYCH OBIEKTACH UŻYTECZNOŚCI PUBLICZNEJ W POLSCE W LATACH 2009-2013}

\author{
Andrei Shpakou ${ }^{1(\mathrm{~A}, \mathrm{C})}$, Iwona Gładysz ${ }^{2(\mathrm{~A}, \mathrm{~B}, \mathrm{E}, \mathrm{E}, \mathrm{G})}$, Agnieszka Sikora $^{3(\mathrm{D}, \mathrm{E})}$, \\ Małgorzata Wójtowicz-Bobin ${ }^{3(\mathrm{~F})}$, Maria Kozioł-Montewka ${ }^{2(\mathrm{C}, \mathrm{D}, \mathrm{E})}$ \\ ${ }^{1}$ Department of Sport Medicine and Rehabilitation, Faculty of Physical Education, \\ Yanka Kupala State University of Grodno, Belarus \\ ${ }^{2}$ Department of Nursing, Faculty of Health Sciences and Social Sciences, \\ Pope John Paul II State School of Higher Education in Biała Podlaska, Poland \\ ${ }^{3}$ Department of Medical Microbiology, Medical University of Lublin, Poland
}

Authors' contribution Wkład autorów: A. Study design/planning zaplanowanie badań B. Data collection/entry zebranie danych C. Data analysis/statistics dane - analiza i statystyki D. Data interpretation interpretacja danych E. Preparation of manuscript przygotowanie artykułu F. Literature analysis/search wyszukiwanie i analiza literatury G. Funds collection zebranie funduszy
Tables: 1

Figures: 3

References: 18

Submitted: 2016 Mar 08

Accepted: 2016 Jun 24

\section{Summary}

Background. Civilizational changes, including urbanisation and industrialisation, created the conditions for the development of new pathogens colonising water networks which endanger human health and life. The aim of the study was to assess the contamination of water supply systems in public buildings by Legionella spp. a pathogenic group of Gram-negative bacteria. Material and methods. The material samples were taken from the hot water supply systems of 41 buildings: school dormitories, boarding schools, educational centres, student dormitories. Results. In all analysed years, there were samples in which the applicable standards were exceeded, as specified by the regulation on the quality of water intended for human consumption. The highest percentage of negative samples was found in 2012 , with as many as $81.1 \%$, and the lowest one in $2011-35.3 \%$. Positive samples obtained in the first and subsequent tests were detected in $20.0 \%$ of the tested facilities. The change from positive to negative values was found in $30.0 \%$ of the tested water networks. There were also cases of negative samples both in the first and subsequent tests, which was detected in $50.0 \%$ of the facilities.

Conclusions. 1 . An excessive amount of the officially permissible value of Legionella was found in $53.9 \%$ of the examined hot water samples. 2 . The obtained results confirm the necessity of modernising and doing elementary repairs in water supply networks.

Keywords: Legionella spp., Legionnaires' Disease, hot water distribution systems, public utility buildings

\section{Streszczenie}

Wprowadzenie. Zmiany cywilizacyjne w tym urbanizacja i industrializacja stworzyły warunki do rozwoju nowych patogenów kolonizujących sieć wodną, które zagrażają zdrowiu i życiu ludzi. Celem pracy była ocena zanieczyszczenia systemów wodnych $w$ budynkach użyteczności publicznej przez bakterie Legionella sp.

Materiał i metody. Materiałem były próbki wody ciepłej pobrane z wewnętrznej instalacji wodociągowej 41 obiektów: bursy szkolne, internaty, ośrodki szkolno-wychowawcze, domy studenta.

Wyniki. Próbki przekraczające obowiązujący normatyw, określony rozporządzeniem w sprawie jakości wody przeznaczonej do spożycia przez ludzi, stwierdzono we wszystkich analizowanych latach. Najwyższy odsetek próbek negatywnych stwierdzono w roku 2012 aż 81,1\%, najniższy w roku 2011 - 35,3\%. Próbki pozytywne uzyskane w pierwszym i kolejnych badaniach, stwierdzono w 20,0\% badanych obiektów. Konwersję próbek pozytywnych w negatywne stwierdzono w 30,0\% badanych obiektów. Próbki negatywne nieobecne w pierwszym i kolejnych badaniach wykryto w 50,0\% obiektów.

Wnioski. 1. Przekroczenie obowiązującej dopuszczalnej wartości bakterii Legionella sp. stwierdzono w 53,9\% badanych próbek wody ciepłej. 2 . Uzyskane wyniki badań potwierdzają konieczność modernizacji i zasadniczych remontów sieci wodnej.

Słowa kluczowe: Legionella sp., choroba legionistów, systemy dystrybucji wody ciepłej, budynki użyteczności publicznej

Address for correspondence / Adres korespondencyjny: Andrei Shpakou, Yanka Kupala State University of Grodno, Faculty of Physical Education, Department of Sport Medicine and Rehabilitation, 22 Ozheshko str., 230023 Grodno, Belarus, e-mail shpakofff@tut.by, phone: +375 152754908

Copyright: (C) 2017 Pope John Paul II State School of Higher Education in Biała Podlaska, Andrei Shpakou, Iwona Gładysz, Agnieszka Sikora, Małgorzata WójtowiczBobin, Maria Kozioł-Montewka.

This is an Open Access journal, all articles are distributed under the terms of the Creative Commons Attribution-NonCommercial-ShareAlike 4.0 International (CC BY-NC-SA 4.0) License (http://creativecommons.org/licenses/by-nc-sa/4.0/), allowing third parties to copy and redistribute the material in any medium or format and to remix, transform, and build upon the material, provided the original work is properly cited and states its license. 


\section{Introduction}

Utility water contamination is a threat to human health and quality of life. The Water Law Act of 18 July 2001 (Journal of Laws 115 No. 1229, as amended) and the Act of 7 June 2001 on collective water supply and collective sewage disposal (Journal of Laws. 2006 No. 123, item 858 as amended) define water intended for human consumption as primary or post-treatment water for food preparation or other domestic purposes, irrespective of its origin, whether it is delivered from distribution networks, tanks, in bottles or containers [1, 2]. Implementing regulation to the Act on Collective Water Supply and Collective Sewage Disposal of June 7, 2001, is the Regulation of Minister of Health of November 13, 2015 r. on the quality of water intended for human consumption (OJ 2015 item 1989). The discussed regulation defines microbiological standards which should be met by hot water [1,3]. Due to the epidemiological threat and an increase in the number of cases of legionellosis, the regulation introduced the requirement to test hot water for the presence of Legionella spp.[4, 5].

The etiological agent of Legionnaires' disease are bacteria of the Legionella genus. Three clinical forms of Legionnaire's disease have been described so far:

- a severe type of pneumonia (Legionnaires' disease, a pulmonary form);

- Pontiac fever (Lochgoilhead fever)

- the extrapulmonary form [6].

Legionella-caused pneumonia accounts for $1 \%$ to $5 \%$ of the cases, whereas Pontiac fever - for between 90 and $98 \%$ of all cases caused by bacteria of the Legionella genus [6]. Most often infection occurs due to breathing in the bacteria suspended in water droplets. The occurrence of the first clinical symptoms of Legionnaire' disease and its severity depends on the number of bacteria found in the water mist (droplets) and one's immunity [7].

The information concerning the presence of Legionella spp. in water supply networks of buildings intended for collective residence is significant in the light of the above laws as well as health requirements and the need of maintaining a water network so that it does not threaten the residents' health. The worldwide reports on the frequency of individual cases of the disease or its outbreaks point to the severity of the problem. They range from 503 to 688 cases per year in Germany, from 1170 to 1540 per year in France, from 706 to 1231 per year in Spain and from 231 to 401 per year in the United Kingdom [8, 9 10]. In Poland, this problem is underestimated and studies concerning contamination of water in supply networks in residential buildings are fragmentary.

The aim of the study was to assess contamination of the water supply installations with Legionella spp. in various public buildings, such as school dormitories, boarding schools, educational centres, student dormitories and analyse the bacterial eradication rate.

\section{Material and methods}

The material for the assessment of health risks posed by Legionella spp. consisted of about 303 hot water samples with a volume of $500 \mathrm{ml}$ or $1000 \mathrm{ml}$ obtained from the internal water supply installations in 41 buildings, such as school dormitories, boarding schools, educational centres or student dormitories.

The water samples were taken by the staff of 5 Sanitary and Epidemiological Stations responsible for their respective areas, as part of water quality monitoring procedure in the period from January 2009 to December 2013. Table 1. shows the number of hot water samples taken for tests in particular years.

The water samples were received by mail or during visits at the Sanitary-Epidemiological Stations. The samples taken from the hot water supply system were tested in accordance with applicable standards and the regulations:

1. PN-EN ISO 11731-2:2008”Water quality - Detection and quantification of Legionella bacteria- Part 2: Methodology for membrane filtration of water with a small number of bacteria".

2. PN-IS011731, December 2002 "Water quality. Detection and quantification of bacteria of Legionella type".

3. PN-EN ISO19458:2007 "Water quality. Obtaining samples for microbiological analysis".

4. Regulation of Minister of Health dated 29 March 2007 (Dz. U. (Journal of Laws) No. 61, item 417, as amended) on the quality of water intended for human consumption.

In accordance with the above-mentioned Regulation, the sites for sampling hot water were:

1. The outflow duct of the hot water tank or the nearest utility outlet.

2. The utility outlet located the furthest away from the hot water tank.

3. The water return to the water heater.

4. The selected intermediate points (numbers depending on the size of the network).

5. If the tested network consisted of more than one water circuit, hot water samples were taken from each of them. 
Table 1. Number of hot water samples taken in the examined public utility buildings per each year between 2009 and 2013

\begin{tabular}{|c|c|}
\hline Year & Number of samples: \\
\hline 2009 & 19 \\
\hline 2010 & 49 \\
\hline 2011 & 68 \\
\hline 2012 & 111 \\
\hline 2013 & 56 \\
\hline Total & $\mathbf{3 0 3}$ \\
\hline
\end{tabular}

\section{Results}

The results received from the Sanitary-Epidemiological Stations were subjected to statistical analysis using STATISTICA 7.1 programme. The percentage of samples containing Legionella spp. in hot water supply networks was calculated Besides, it was measured how the passage of time affects the level of contamination in a particular building. The analysis was conducted separately for each year in the period 2009-2013. To detect statistically significant differences, the Chi square Pearson independence test was used with the significance level at $p \leq 0.05$.

According to the Regulation of the Minister of Health of 13th November 2015 on the quality of water intended for human consumption (Journal of Laws 2015 item. 1989), evaluation of contamination with Legionella spp. is dependent on the value of $\mathrm{CFU} / 100 \mathrm{ml}$ :

a) lack or negligible $<100 \mathrm{CFU} / 100 \mathrm{ml}$

b) medium $>100 \mathrm{CFU} / 100 \mathrm{ml}$

c) high $>1,000 \mathrm{CFU} / 100 \mathrm{ml}$

d) very high> $10000 \mathrm{CFU} / 100 \mathrm{ml}$

The samples containing $>100 \mathrm{CFU} / 100 \mathrm{ml}$ were classified as positive. Negative and positive samples - those containing $>100 \mathrm{CFU} / 100 \mathrm{ml}$. and $<100 \mathrm{CFU} / 100 \mathrm{ml}$. Negative samples - the ones containing <100 CFU/100 ml, according to the current Regulation of the Minister of Health on the quality of water intended for human consumption.

Figure 1. shows the results of the tests conducted in school dormitories, boarding schools, education centres, student dormitories, separately for the years 2009-2013.

Results: The samples exceeding the applicable standards were found in all analysed years. The norm is specified by the regulation on the quality of water intended for human consumption. The highest percentage of water systems where negative and positive samples were found was observed in the year 2013, i.e. 50\%. In 2009 and 2013, the percentage of facilities in which positive samples were detected amounted to 6.25\% in 2009 and $9.09 \%$ in 2013 respectively. Negative samples were found in all of the analysed years. The highest percentage of networks when the samples were negative was observed in the year 2009 - as low as $87.50 \%$, whereas the lowest in the year 2013 - 50\%. However, it could also be said that there is no increase in the number of facilities with negative results in the analysed years 2009 - 2013.

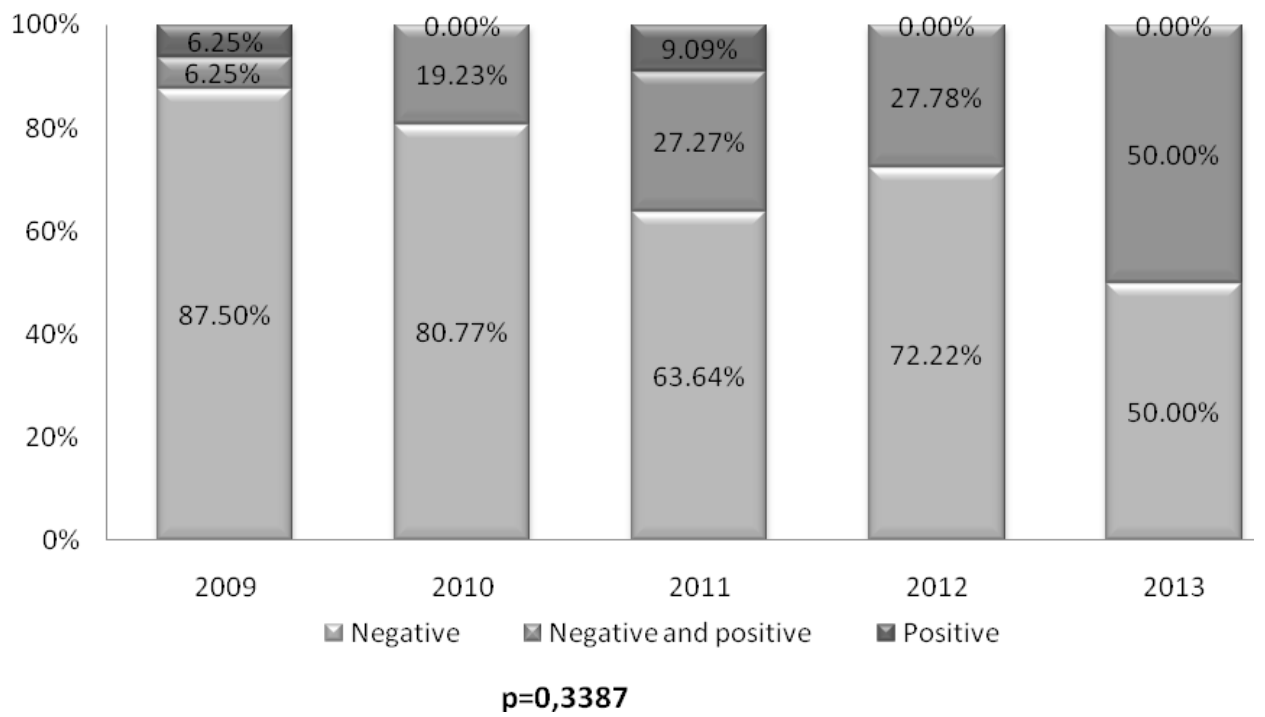

Figure 1. Test results of the water supply networks in the examined public buildings separately for the years 2009-2013 
Figure 2. shows the percentage of the examined hot water samples, separately for the years 2009 - 2013. The highest percentage of negative samples was found in 2012, with as many as $81.1 \%$ of the reported cases, and the lowest one in $2011-35.3 \%$. High Legionella spp. contamination was detected in $2011-8.8 \%$ and in the year 2012 $-8.1 \%$. The values of $>10000 \mathrm{CFU} / 100 \mathrm{ml}$ in positive samples in the year 2011 reached $1.5 \%$.

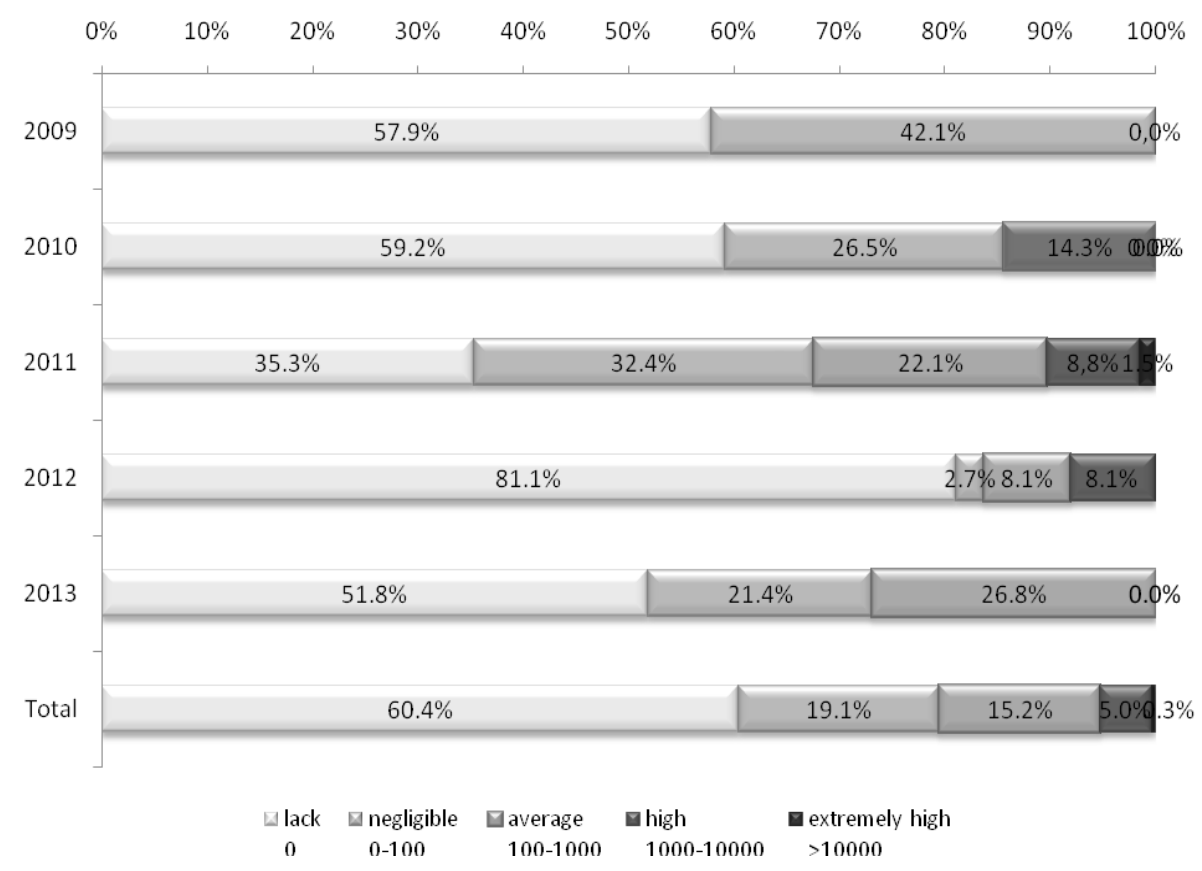

Figure 2. Contamination of the samples in all examined water supply networks in the years 2009-2013

In order to assess the quantitative change in Legionella spp. values in the hot water supply networks of the examined facilities, 20 of them were selected. Then, water samples were collected from their hot water supply circuits in two or more consecutive years.

Figure 3. shows the results obtained in the examined facilities, in which:

1. positive samples were found in the first and follow-up tests,

2. negative samples changed into positive ones,

3. positive samples converted into negative ones,

4. there were no positive samples in the first and follow-up tests.

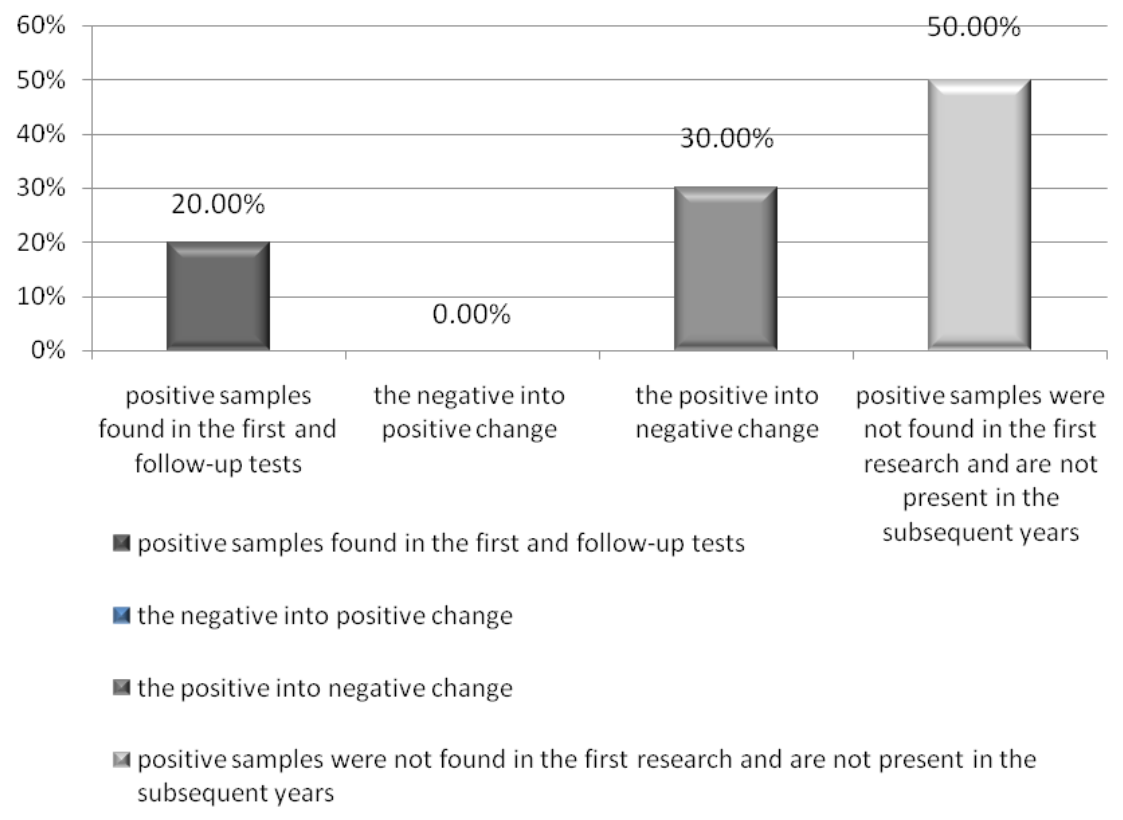

Figure 3. Change in Legionella spp. values in the examined facilities in the years 2009-2013 
Positive samples obtained in first and subsequent tests were found in $20.0 \%$ of the surveyed facilities. There were no negative into positive changes. However, the positive into negative change were observed in $30.0 \%$ of the examined water systems. What was positive about the whole research was that there are $50.0 \%$ of water networks with negative samples in first and follow-up tests.

\section{Discussion}

The natural environment of the bacteria of the genus Legionella is water environment, forming a reservoir from which they spread to colonise hot and cold water supply systems. Bacteria gain access to the water supply network through water treatment plants, from which they move into ventilation and air-conditioning systems. Having been transferred to the water supply installation, the bacteria may undergo rapid multiplication. Artificial reservoirs, apart from the water supply networks, include: equipment for water massage (bubble pools), circulations of heating and cooling water in air-conditioners, cooling towers, steam condensers, as well as medical equipment, respirators, inhalers, dialysis devices, dental turbines, moisturizing equipment, fountains, sprinklers, car washes, humidification systems and other devices that produce water mist with droplets with a diameter $<5$ microns [11].

Modern swimming pools also pose a high risk. They are recreational complexes, which increase their attractiveness for swimmers by offering: geysers, water whips, underwater massage, cascades, artificial rivers, water slides, hydro massage tubs and saunas. The Polish legislation does not require controlling pool waters in order to detect the bacteria of the genus Legionella [12].

Bacteria of the genus Legionella occurring in water networks are an etiologic factor of Legionnaires' disease. They also pose a threat for human life and health. The obligation to monitor the quality of water intended for human consumption in public buildings where smaller or larger groups of people reside is determined by the Regulation of the Minister of Health of 13 November 2015 on the quality of water intended for human consumption (Journal of Laws 2015 item. 1989).

The obligation to notify about and register cases of Legionnaires' disease in Poland was introduced in 2002 pursuant to the Act of 6 September 2001 on infectious diseases and infections (Journal of Laws of 2001 No. 126, item. 1384). Since 2008, the rules and procedures of preventing and fighting human infections and infectious diseases have been regulated by the Act on preventing and fighting human infections and infectious diseases of 5 December 2008 (Journal of Laws 2013, item 947). Legionellosis was added to the list of infections and infectious diseases in an annex to the Act in question [13]. Legionellosis is registered as legionnaires' disease (alpha-numeric designation A48.1) and Pontiac fever (alpha-numeric designation A48.2), according to the International Statistical Classification of Diseases and Related Health Problems ICD-10), introduced by the World Health Organization (WHO). ICD-10 has been in force in Poland since 1996 [14].

Since 2005 Legionella spp. and L. pneumophila have been registered as biological factors harmful to health in the work environment on the basis of the Regulation of the Minister of Health of 22 April 2005 (Journal of Laws No. 81, item 716) on biological factors harmful to health in the work environment and health protection of workers professionally exposed to these factors [15]. Regulations concerning the protection of workers from exposure to biological agents in the workplace is also regulated by European law, i.e. the Directive 2000/54/EC. Bacteria Legionella spp. and L. pneumophila, where they are classified as biological agents in group 2, which can cause disease in humans and endanger workers' health [16].

School dormitories, boarding schools, education centres, student dormitories belong to a group of facilities that were designed and built before the appearance of the problem of Legionnaires' disease in Poland. It should be noted that the examined group of buildings and systems consist mostly of old and often underfunded facilities. They require modernization and major repairs, including the water supply networks.

Our own studies have shown the presence of positive samples as well as negative and positive ones in some facilities. There were also those water networks in which no samples exceeded the applicable standards (they were negative).

The degree of contamination of water samples by bacteria was also presented Legionella sp. on the scale from low to very high values. The positive to negative change in_some samples found during the research indicates a positive direction of the changes, which is probably the result of properly conducted sanitary and epidemiological supervision, as well as the attention paid by public buildings owners to the condition of the hot water supply installations.

The research conducted by Matejuk et al. in kindergartens and school dormitories, showed an excessive presence of Legionella spp. in 4 out of 11 hot water samples. The research conducted by Wojdyła-Bucior et al. shows that from in 57 water samples collected in student dormitories, 38 samples exceeded the applicable standards, which constitutes $66.6 \%$. Among the positive values, 33 samples of hot water exceeded values of $>100 \mathrm{CFU} / \_100 \mathrm{ml}$, which constitutes $57.8 \%$ of the obtained samples. 
The available foreign publications which report on the presence of Legionella spp. in buildings of this type do not exist. The small number of research on risk assessment at school dormitories, dormitories, schools and education centres, student homes does not allow for drawing comparison between our own research results and other authors' findings. Our findings are of considerable significance as they demonstrate a very high degree of bacterial contamination in the water supply networks of buildings intended for public or collective residence.

Having in mind the underinvestment of this type of buildings, one should consider an introduction of statutory specific-purpose grants for repairs or replacements of old installations. Further, it is advisable to introduce mandatory notification if the water does not meet the standards and Legionella spp. bacteria are present in the hot water supply networks in collective residence buildings.

\section{Conclusions}

1. Legionella spp. bacteria in excess of the applicable standards was found in $53.9 \%$ of the examined warm water samples.

2. The obtained results indicated that modernization and general repairs of water supply networks are needed.

\section{References:}

1. Ustawa prawo wodne z dnia 18 lipca 2001 (Dz. U. 115 Nr 1229 ze zm.) (in Polish).

2. Rozporządzenie Ministra Zdrowia z dnia z dnia 13 listopada 2015 r. w sprawie jakości wody przeznaczonej do spożycia przez ludzi. Ministerstwo Zdrowia (Dz.U. 2015 poz. 1989) (in Polish).

3. Ustawa o zbiorowym zaopatrzeniu w wodę i zbiorowym odprowadzaniu ścieków z dnia 7 czerwca 2001 roku (Dz. U. 2006 Nr 123, poz. 858 ze zm.) (in Polish).

4. Wichrowska B. Interpretacja zmian w rozporządzeniu Ministra Zdrowia z dnia 29 marca 2007 r. dotyczącym jakości wody przeznaczonej do spożycia przez ludzi. OchrŚrod. 2007; 4 (29): 1-10 (in Polish).

5. Maziarka D. Nowe regulacje prawne dotyczące jakości wody przeznaczonej do spożycia przez ludzi rozporządzenie Ministra Zdrowia z dnia 29 marca 2007 r. In: TokarczukA, editor. Kierunki rozwoju zaopatrzenia w wodę do picia. Materiały Konferencyjne IV Konferencji Naukowo-Technicznej, 9-11 maja 2007 Nowogród k/ Łomży. Warszawa; Seidel-Przywrecki. 2007. p. 17-24 (in Polish).

6. Pancer K, Stypułkowska-Misiurewicz H. Epidemiologia zachorowań wywołanych przez Legionella sp. Nowa Med. 2009 ;1: 61-65 (in Polish).

7. Lück C. Legionella pneumophila: genetic diversity of patients and environmental isolates. Bund Gesun. 2011; 54(6): 693-698.

8. Legionnaires' disease in Europe. Surveillance Report 2009 European Centre for Disease Preventionand Control. [cited 2016 Mar 08]. Available from: http://ecdc.europa.eu/en/publications/surveillance_reports/ Pages/index.aspx.

9. Legionnaires' disease in Europe. European Centre for Disease Prevention and Control, Surveillance Report 2010; 20. [cited 2016 Mar 08]. Available from: http://ecdc.europa.eu/en/publications/surveillance_reports/ Pages/index.aspx.

10. Legionnaires' disease in Europe. Surveillance Report 2011European Centre for Disease Prevention and Control. [cited 2016 Mar 08]. Available from: http://ecdc.europa.eu/en/publications/surveillance_reports/ Pages/index.aspx.

11. Krogulska B, Matuszewska R. „Bakterie z rodzaju Legionella - obowiązujące w Polsce regulacje prawne”, „Bezpieczna woda w szpitalu” warsztaty na temat zakażeń szpitalnych wywoływanych przez pałeczki Legionella spp. Instytut Gruźlicy i Chorób Płuc w Warszawie, Narodowy Instytut Zdrowia Publicznego; 24 Oct 2008 (in Polish).

12. Krogulska B. Zwalczanie bakterii z rodzaju Legionella w instalacjach basenowych i urządzeniach rekreacyjnych. In: Piechurski F, editor Instalacje Basenowe. Gliwice. Instytut Inżynierii Wody i Ścieków; 2009, p. 202217 (in Polish).

13. Ustawa o zapobieganiu oraz zwalczaniu zakażeń i chorób zakaźnych u ludzi z dnia 5 grudnia 2008 (Dz. U. 2013, poz. 947) (in Polish).

14. Międzynarodowa Statystyczna Klasyfikacja Chorób i Problemów Zdrowotnych ICD-10 - X Rewizja, Tom I i II. Warszawa: Centrum Systemów Informacyjnych Ochrony Zdrowia; 2012 (in Polish).

15. Rozporządzenie Ministra Zdrowia z dnia z dnia 22 kwietnia 2005 w sprawie szkodliwych czynników biologicznych dla zdrowia w środowisku pracy oraz ochrony zdrowia pracowników zawodowo narażonych na te czynniki. Ministerstwo Zdrowia (Dz. U. Nr 81, poz. 716) (in Polish). 
16. Dyrektywa Parlamentu Europejskiego i Rady z dnia 18 września 2000 r. w sprawie ochrony pracowników przed ryzykiem związanym z narażeniem na działanie czynników biologicznych w miejscu pracy (Dyrektywa 2000/54/WE) (in Polish).

17. Wojtyła-Buciora P, Chrzanowska E, Marcinkowski JT. Występowanie pałeczek Legionella sp. w instalacjach ciepłej wody użytkowej w zakładach opieki zdrowotnej oraz budynkach użyteczności publicznej. Hyge Public Health 2013; 48(3): 327-332 (in Polish).

18. Matejuk A, Posmyk U, Simon K. Występowanie pałeczek Legionella spp. w instalacjach wodnych obiektów użyteczności publicznej w województwie opolskim, w latach 2010-2011. Przegląd Epidemiologiczny 2012; 66: 623-628 (in Polish). 